\title{
Nosocomial Infections and Associated Risk Factors in Geriatric Patients in the Intensive Care Unit
}

\author{
Ayşe İnci', Ayşegül Karabay², Suat Erus ${ }^{3}$, Yavuz Demiraran² \\ ${ }^{1}$ Clinic of Infectious Disease and Clinical Microbiology, Kanuni Sultan Süleyman Training and Research Hospital, İstanbul, Turkey \\ ${ }^{2}$ Clinic of Anesthesia and Reanimation, Kanuni Sultan Süleyman Training and Research Hospital, İstanbul, Turkey \\ ${ }^{3}$ Department of Thoracic Surgery, Koç University School of Medicine, İstanbul, Turkey
}

\begin{abstract}
Aim: The elderly population increases worldwide. The purpose of this study was to evaluate nosocomial infections (NI) detected in geriatric patients and to determine the risk factors leading to their development.

Materials and Methods: Patients monitored in our hospital's Intensive Care Unit (ICU) were evaluated daily by intensive care and infectious disease specialists, including surveillance by our Infection Control Committee. We included the patients aged $\geq 65$ years who were monitored in the adult ICU between January and December 2014, using the methods of retrospective file screening and computer record review. Patients were classified into two groups: patients with and without NI.

Results: In total, 222 (38.07\%) patients were $\geq 65$ years old. $44 \mathrm{NI}$ events were detected in 27 patients. Groups were compared with respect to age; sex; presence of mechanic ventilation (MV), central venous catheterization (CVC), cerebrovascular disease, chronic obstructive disease, diabetes mellitus; and mortality. The presence of MV, CVC, and mortality were seen to be significantly higher in patients with NI compared with those without. The most common Nls found were sepsis and pneumonia. The most common infectious agent was Acinetobacter.

Conclusion: Nls observed in hospital ICUs are common, but largely preventable, conditions. A systematic approach and well-disciplined empiric therapy are very important. Our study revealed that the mortality rate is high in elderly patients who develop $\mathrm{NI}$, and $\mathrm{NI}$ is more commonly seen in patients who undergo invasive interventions. We believe that using invasive interventions as little as possible in this group may improve their treatment success and outcome.
\end{abstract}

Keywords: Nosocomial infections, risk factors, geriatric patients

\section{Introduction}

As the elderly population increases worldwide, the evaluation and care of elderly patients becomes very important. With increases in the geriatric population, the number of elderly patients admitted to intensive care units (ICUs) has also increased (1, 2).

The courses of elderly patients in ICUs may differ. Elderly patients in ICUs represent a complex patient group; they may have acute exacerbations of underlying chronic diseases or problems involving many organ systems. Acute exacerbations of a chronic disease can become more complex because of the general decline in physiological reserves that comes with advanced age. Patients over 65 years of age account for $42 \%-52 \%$ of those in ICUs in the USA (3-5).
Nosocomial infections (NI) are an important health issue, both globally and in Turkey, because of their economic burden and high mortality rates. A decrease in the rates of $\mathrm{NI}$ has been achieved in developed countries as a result of infection control studies initiated earlier by these countries. Detection of problems has been delayed in developing countries because of their lag in initiating such studies. Developing countries have a 2-20-fold higher risk of NIs compared with developed countries $(6,7)$.

Despite the fact that elderly patients are at higher risk for developing NIs, the frequency, risk factors, and types of hospital-acquired infections in geriatric patients are not well known $(8,9)$.

The purpose of this study was to evaluate Nls detected in geriatric patients and to determine the risk factors leading to their development.

This study was presented at the $7^{\text {th }}$ Eurasian Congress of Infectious Diseases (EACID), 30 September-3 October, 2015, Tbilisi, Georgia.

Correspondence to: Ayşe İnci e-mail: ays.2004@yahoo.com

Received: 28.10.2016 Accepted: 07.12.2016

(C) Copyright 2016 by Emergency Physicians Association of Turkey - Available online at www.eajem.com

DOI: 10.5152/eajem.2016.35744 


\section{Materials and methods}

This study was conducted between January 1 and December 1,2014 , with the approval of the hospital ethics committee (Kanuni Sultan Suleyman Training and Research Hospital, Ethics Committee Decision No. 164/32, dated November 24, 2014).

Patients monitored in our hospital's ICU were evaluated daily by intensive care and infectious disease specialists, including surveillance by our Infection Control Committee. In this study, we examined the patients aged $\geq 18$ years who were monitored in the adult ICU between January 2014 and December 2014, using the methods of retrospective file screening and computer record review. We focused on the patients aged $\geq 65$ years.

Subjects were classified into two groups: patients with and without NI. Both groups were then compared with respect to the use of mechanical ventilators (MV) and central venous catheters (CVC); the presence of selected types of underlying disease (such as cerebrovascular disease (CVD), chronic obstructive pulmonary disease (COPD), diabetes mellitus (DM); and mortality.

Nls were diagnosed according to the criteria of Centers for Disease Control and Prevention (CDC) in patients who were being monitored by our hospital-based and laboratory-based active surveillance methods.

Cultures of elderly patients detected to have NI were collected from their blood, urine, and site of infection on the day they developed the infection. The number of infections in these patients and the distribution of their infections by body system and causal agents (microorganisms) were recorded.

Identification of the growing microorganisms and antibiotic sensitivity testing of blood cultures were performed using an automated system. The Statistical Package for the Social Sciences version 15.0 (SPSS Inc.; Chicago, IL, USA) program was used for statistical evaluation: mean \pm standard deviation, Chi-square tests, and MannWhitney $U$ tests were calculated for descriptive statistics and tests of statistical significance. A p-value $<0.05$ was considered statistically significant.

\section{Results}

In our study, 583 patients were admitted to the adult ICU, 222 (38.1\%) were $\geq 65$ years old. $44 \mathrm{NI}$ events were detected in 27 patients.

When patients with and without NI were compared with respect to age; sex; presence of MV, CVC, CVD, COPD, DM, and mortality, the presence of $\mathrm{MV}$ and CVC and mortality were seen to be significantly higher in patients with $\mathrm{NI}$ compared with those without. No differences between study groups were detected in the other examined parameters (Table 1). The most common Nls found were sepsis and pneumonia. The most common infectious agent was Acinetobacter (Table 2).

\section{Discussion}

Patients monitored in ICUs are characterized by impaired general health status, frequent exposure to invasive interventions, use of broad-spectrum antibiotics, and longer duration of hospital stays. Infection is one of the most important causes of morbidity and mortality in this setting. Despite the fact that only $5 \%-10 \%$ of hospitalized patients are treated in ICUs, $20 \%-25 \%$ of all NIs occur in these units (10-12).
Table 1. Comparison of characteristics of geriatric patients with and without NI (n/\%)

\begin{tabular}{|c|c|c|c|}
\hline Mean age & $\begin{array}{c}\text { Patients } \\
\text { with NI } \\
\mathbf{N}=\mathbf{2 7}(\mathbf{1 2 . 2} \%) \\
74.85 \pm 9.73 \text { years }\end{array}$ & $\begin{array}{c}\text { Patients } \\
\text { without } \mathbf{N I} \\
\mathbf{N}=195(\mathbf{8 7 . 8 \% )} \\
76.64 \pm 6.86 \text { years }\end{array}$ & $\begin{array}{c}\mathbf{P} \\
\text { value } \\
0.113\end{array}$ \\
\hline Sex: M/F & $15 / 12(55.6 / 44.4)$ & $75 / 120(38.5 / 61.5)$ & 0.09 \\
\hline Presence of CVC & $27(100)$ & $87(44.6)$ & $<0.001$ \\
\hline Presence of MV & $27(100)$ & $72(36.9)$ & $<0.001$ \\
\hline Presence of COPD & $8(29.6)$ & $58(29.7)$ & 0.99 \\
\hline Presence of DM & $6(22.2)$ & $60(30.8)$ & 0.36 \\
\hline Presence of CVD & $2(7.4)$ & $34(17.4)$ & 0.18 \\
\hline Mortality rate & $23(85.2)$ & $28(14.4)$ & $<0.001$ \\
\hline
\end{tabular}

Table 2. Number and percent of Nls developed by microorganism (n/\%)

\begin{tabular}{|l|c|}
\hline & N (\%) \\
\hline Acinetobacter baumannii & $16(36.4)$ \\
\hline Pseudomonas species & $11(25)$ \\
\hline MRSA + MRCNS & $8(18.2)$ \\
\hline Klebsiella pneumoniae & $24(4.6)$ \\
\hline Candida albicans & $3(6.8)$ \\
\hline Escherichia coli & $3(6.8)$ \\
\hline Serratia marcescens & $1(2.3)$ \\
\hline Factors & $44(100)$ \\
\hline $\begin{array}{l}\text { MRSA: methicillin-resistant Staphylococcus aureus; MRCNS: methicillin-resistant } \\
\text { coagulase-negative staphylococ; Nl: nosocomial infections }\end{array}$ \\
\hline
\end{tabular}

In our study, the rate of elderly patients being admitted to the adult ICU was $38.1 \%$. This rate was determined to be $49.8 \%$ in a study by Ozdemir et al. (2) and 48.6\% in another study (13).

The human lifespan is being extended by new developments, and interventions to extend the lifespan may lead to infections. Hospitalized elderly patients are at high risk of NIs because of the predisposition of underlying chronic diseases, physiological changes of aging, and invasive interventions $(14,15)$.

Our study revealed that the presence of CVC and MV was significantly higher in patients with NI than in those without; but no difference was detected in other examined parameters. Our study also revealed that the mortality rate was statistically significant and higher in patients who developed $\mathrm{NI}$ compared with those who did not.

In another Turkish study conducted with 433 patients, of whom 288 were $>65$ years of age, the presence of MV and CVC and the use of broad-spectrum antibiotics were found to be higher in elderly patients who developed $\mathrm{NI}$ compared with those who did not. No associations were detected between the presence of DM, malignancy, or COPD and the development of $\mathrm{NI}(2)$.

Similar to our findings, a study by Ribas and Gontijo Filho (9) also reported that the presence of CVC and MV was higher in elderly pa- 
Table 3. The most common infections and microorganisms observed in selected studies on NI (\%)

\begin{tabular}{|l|c|c|c|c|}
\hline Study & Year & Age group & Most common infection & Most common microorganisms \\
\hline Beaujean et al. (19) & 1997 & Geriatric & UTI & - \\
\hline Stéphan et al. (17) & 2001 & $>75$ years & Pneumonia & - \\
\hline Ribas et al. (9) & 2003 & $\geq 65$ years & Surgical site & - \\
\hline Erbay et al. (16) & 2003 & Adults & Pneumonia & Pseudomonas aeruginosa \\
\hline Ellidokuz et al. (20) & 2003 & $\geq 65$ years & Surgical site & - \\
\hline Ozdemir et al. (2) & 2012 & $\geq 65$ years & Pneumonia & - \\
\hline Oberoi et al. (21) & 2012 & $\geq 65$ years & UTI & Escherichia coli \\
\hline Mythri et al. (15) & 2014 & $43-72$ years & UTI & - \\
\hline Erdem et al. (18) & 2014 & Adults & Pneumonia & Acinetobacter species \\
\hline Present study & 2014 & $\geq 65$ years & Pneumonia & Acinetobacter species \\
\hline UTI: urinary tract infection; Nl: nosocomial infections & & & \\
\hline
\end{tabular}

tients who developed NI. A study by Mythri et al. (15) revealed that NIs in elderly patients were associated with invasive interventions.

A study by Erbay et al. (16) reported a mortality rate of $60.9 \%$ for patients with $\mathrm{NI}$ and $22.1 \%$ for those without, which was a statistically significant finding (16). However, a study by Stéphan et al. (17) reported that patients over 75 years of age were not at an increased risk of $\mathrm{NI}$ development or death.

According to the literature, $\mathrm{NI}$ in elderly patients commonly involves pneumonia and Acinetobacter. Summary findings of selected studies related to this issue are listed in Table 3.

A study by Aydemir et al. (22), which was also conducted in Turkey, examined infection consultations for elderly patients and reported the most common diagnoses as community-acquired pneumonia, nosocomial pneumonia, and urinary tract infection.

Nosocomial pneumonia developed in an ICU setting increases morbidity and mortality (2). In a study by Alp et al. (23), the mortality rate was reported to be $65 \%$ for the nosocomial pneumonia group and $26 \%$ for the control group; whereas the study of Pancharti et al. (24) reported the mortality rate for the nosocomial pneumonia group to be $42 \%$

A study by Cevik et al. (25), conducted in a neurological ICU, reported a mortality rate of $69 \%$ for $\mathrm{NI}$ and demonstrated that $\mathrm{MV}$, use of steroids, parenteral nutrition, and a low score on the Glasgow Coma Scale heightened mortality.

We believe that the high mortality rate of $85 \%$ in our study may be attributed to the fact that all NIs occurring in our geriatric patients were pneumonia and sepsis, and the rates of MV and CVC were very high.

\section{Conclusion}

Nls observed in hospital ICUs are common, but largely preventable, conditions. A systematic approach and well-disciplined empiric therapy are very important. Our study revealed that the mortality rate is high in elderly patients who develop $\mathrm{NI}$, and $\mathrm{NI}$ is more commonly seen in patients who undergo invasive interventions. We believe that using invasive interventions as little as possible in this group may improve their treatment success and outcome.

Ethics Committee Approval: Ethics committee approval was received for this study from the Ethics Committee of Kanuni Sultan Süleyman Training and Research Hospital (24.11.2014, Decision No: 164/32).
Informed Consent: Informed consent was not received due to the retrospective nature of the study.

Peer-review: Externally peer-reviewed.

Conflict of Interest: No conflict of interest was declared by the authors.

Financial Disclosure: The authors declared that this study has received no financial support.

\section{References}

1. Yavuz BB. Geriatric evaluation and tests. İç Hastalıkları Derg 2007; 14: 5-17.

2. Ozdemir K, Dizbay M, Dikmen A. Incidence and risk factors of nazocomial infections in elderly and adult patients in intensive care units. Turkish J Geriatrics 2013; 16: 155-60.

3. Ülger Z, Cankurtaran M. Elderly Patient in the Intensive Care Unit. Yoğun Bakım Dergisi 2006; 6: 94-100.

4. Topeli A. Elderly patient in the intensive care unit. Turkish J Geriatrics 2000; 3: 151-4.

5. Erden IA, Kara D, Ayhan B, Uzun Ş. Geriatric patient and intensive care. Akademik Geriatri Dergisi 2012; 4: 115-9.

6. Yalçın NA. Nozokomiyal Gram-negatif çomak infeksiyonları. Klimik Derg 2000; 13: 23-5.

7. Çetinkaya ŞY. Hastane infeksiyonları: Dünya'da ve Türkiye'de mevcut durum ve yeni hedefler. ANKEM Derg 2010; 24: 120-2.

8. Saviteer SM, Samsa GP, Rutala WA. Nosocomial infections in the elderly. Increased risk per hospital day. Am J Med 1988; 84: 661-6. [CrossRef]

9. Ribas RM, Gontijo Filho PP. Comparing hospital infections in the elderly versus younger adults: an experience in a Brazilian University Hospital. Braz J Infect Dis 2003; 7: 210-5.[CrossRef]

10. Yılmaz N, Köse Ş, Ağuş N, Ece G, Akkoçlu G, Kıraklı C. Yoğun bakım ünitesinde yatan hastaların kan kültürlerinde üreyen mikroorganizmalar, antibiyotik duyarlılıkları ve nazokomiyal bakteriyemi etkenleri, ANKEM Derg 2010; 24: 12-9.

11. Vincent JL, Rello J, Marshall J, Silva E, Anzueto A, Martin CD, et al. International study of the prevalence and outcomes of infection in intensive care units. JAMA 2009; 302: 2323-9. [CrossRef]

12. Çetin ES, Kaya S, Pakbaş İ, Demirci M. Yoğun bakım unitelerinde yatan hastalardan izole edilen mikroorganizmalar ve antibiyotik duyarlııkları, Inönü Univ Tıp Fak Derg 2007; 14: 69-73.

13. A Topeli. The outcome of the geriatric patients in the ICU. Crit Care 2001; 5: P249. [CrossRef] 
14. Çalangu S. Yaşlılarda infeksiyon hastalıklarına genel bakış. Klimik Derg 1991; 4: 51-3.

15. Mythri $\mathrm{H}$, Kashinath $\mathrm{K}$. Nosocomial infections in patients admitted in intensive care unit of a tertiary health center, India. Ann Med Health Sci Res 2014; 4: 738-41. [CrossRef]

16. Erbay H, Yalcin AN, Serin S, Turgut H, Tomatir E, Cetin B.et al. Nosocomial infections in intensive care unit in a Turkish university hospital: a 2-year survey. Intensive Care Med 2003; 29: 1482-8. [CrossRef]

17. Stéphan F, Cheffi A, Bonnet F. Nosocomial infections and outcome of critically ill elderly patients after surgery. Anesthesiology 2001; 94: 407-14. [CrossRef]

18. Erdem H, Inan A, Altındis S, Carevic B, Askarian M, Cottle L. et al. Surveillance, control and management of infections in intensive care units in Southern Europe, Turkey and Iran--a prospective multicenter point prevalence study. J Infect 2014; 68: 131-40. [CrossRef]

19. Beaujean DJ, Blok HE, Vandenbroucke-Grauls CM, Weersink AJ, Raymakers JA, Verhoef J. Surveillance of nosocomial infections in geriatric patients. J Hosp Infect 1997; 36: 275-84. [CrossRef]
20. Ellidokuz H, Uçku R, Uysal U, Abacioğlu H. Hospital-acquired infections in elderly patients: results of a West Anatolian University Hospital surveillance. Arch Gerontol Geriatr 2003; 37: 259-63. [CrossRef]

21. Oberoi L, Neki NS, Kaur R, Oberoi R. Changing trends of nosocomial infections in geriatric patients in a tertiary care hospital. JIMSA 2012; 25: 233-4.

22. Aydemir H, Piskin N, Akduman D, Yllmaz O. İnfectious disease consultations in hospitalized elderly patients. Turkish Journal of Geriatrics 2012;15(2):127-33.

23. Alp E, Güven M, Yildiz O, Aygen B, Voss A, Doganay M. Incidence, risk factors and mortality of nosocomial pneumonia in intensive care units: a prospective study. Ann Clin Microbiol Antimicrob 2004; 3: 17. [CrossRef]

24. Pancharti P, Leksawas N, Sukamwang K, Tantisiriwat W, Danchaivijitr S. Impacts of nosocomial infection among elderly patients in Inburi Hospital. J Med Assoc Thai 2005; 88: S83-5.

25. Cevik MA, Yilmaz GR, Erdinc FS, Ucler S, Tulek NE. Relationship between nosocomial infection and mortality in a neurology intensive care unit in Turkey. J Hosp Infect 2005; 59: 324-30. [CrossRef] 